\title{
Childhood Mixed Glioma
}

National Cancer Institute

\section{Source}

National Cancer Institute. Childhood Mixed Glioma. NCI Thesaurus. Code C115195.

A mixed glioma that occurs during childhood. 